\title{
PENGARUH MOTIVASI WISATAWAN LOKAL TERHADAP KEPUTUSAN BERKUNJUNG KE TAMAN KOTA DI KOTA TANGERANG SELATAN
}

\author{
Fikri Abdul Fatah, Bagja Waluya, Yeni Yuniawati \\ Universitas Pendidikan Indonesia \\ yeni@upi.edu
}

\begin{abstract}
One of the famous, and still developing, attractions in South Tangerang are Taman Kota. It is a city-park located at the center of the city, there is a red bridge inside which is very popular among the people of South Tangerang. There is also the tributary of Cisadane and lots of bushy trees, which provide natural shades. There is a decrease in visitors of Taman Kota from 2011 to 2014 because there are a lot of tourism attraction competitors in South Tangerang. One of the efforts done by Taman Kota to increase the decision to visit is by improving the management understanding of tourist motivation. The independent variable in this research is tourist motivation $(X)$ which consists of some sub variables, which are nature, value for money, and physical activities. The dependent variable is the decision to visit $(Y)$ which consists of product selection, brand selection, line of selection, time of visit selection and the frequency attending the attraction. The research types used are descriptive and verification. The method used was an explanatory survey. The samples of this research are 100 respondents, which were drawn by using systematic random sampling. Hypothesis testing data analysis technique used was multiple regressions. Tourists' responses regarding to the motivation in Taman Kota were considered high. The result from this research shows that the most influential sub variable is nature, and the less is on the physical activities. Tourists' responses to the decision to visit were also considered high. Line of the selection indicators got the highest score; meanwhile, the time of visit selection got the lowest score. Based on the testing through SPSS 20 for windows, there is a simultaneous and partial influence between tourist motivation and the decision to visit. The recommendation to the management of Taman Kota to increase the decision to visit is by optimizing the object as tourism appeal for physical activities.
\end{abstract} $\underset{\text { Visit; }}{K e y w}$

Keywords-Tourist Motivation; Decision to

\section{Pendahuluan}

Sektor pariwisata saat ini telah menjadi sektor industri yang sangat besar di dunia. Pertumbuhuan pariwisata saat ini merupakan bentuk nyata dari perjalanan sebuah bisnis global yang memang sangat menjanjikan karena pertumbuhan pariwisata itu sendiri mampu mendorong pertumbuhan ekonomi dunia yang dihasilkan dari pergerakan wisatawannya. Terutama dengan negara yang sangat mengandalkan pariwisatanya. Akhir-akhir ini pariwisata di Indonesia sangat digalakkan oleh pemerintah Indonesia. Pariwisata mempunyai prospek yang sangat baik untuk masa depan bagi Negara Republik Indonesia. Data yang ditunjukkan dari UNWTO (United Nations World Tourism Organization) diperkirakan pada tahun 2020 akan terjadi pergerakkan sebanyak 1,6 miliar wisatawan dengan total perbelanjaan sebesar USD 2.000 miliar.

Menanjaknya pengunjung yang datang ke Indonesia dalam beberapa tahun terakhir ini berdampak juga pada menaiknya wisatawan yang berkunjung ke provinsi Banten. Kota yang bersebelahan dengan Daerah Khusus Ibukota ini pun memiliki karakteristik wisatanya yang berbeda-beda di setiap kota dan kabupaten di wilayah Banten itu sendiri. Salah satu kota yang terkena dampak dari berkembangnya pariwisata di Provinsi Banten adalah kota Tangerang Selatan.

Tangerang selatan merupakan kota paling timur dari provinsi Banten. Batas wilayah Kota Tangerang Selatan yaitu kota Tangerang di sebelah utara, Kabupaten Tangerang di sebelah barat, Kota Bogor di sebelah selatan, dan Provinsi DKI Jakarta di bagian timur. Hal yang menguntungkan bagi kota Tangerang Selatan adalah dengan berdekatannya jarak dengan ibukota DKI Jakarta. 
Pada dasarnya keputusan untuk melakukan perjalanan wisata diadaptasi dari teori keputusan berkunjung, yaitu seseorang mengeluarkan uang untuk mendapatkan kepuasan dan pengalaman. Menurut Kotler dan Keller (2012: 170), proses pengambilan keputusan seseorang wisatawan melalui lima fase yaitu pemilihan produk wisata, pemilihan suatu merek, pemilihan saluran pembelian, pemilihan waktu kunjungan, dan jumlah kunjungan.

Menurut Hudson (2008: 40) mengungkapkan perilaku konsumen merupakan bagian dari manajemen pemasaran pariwisata. Dengan memahami pola perilaku wisatawan maka pemasar dapat mengetahui dan menargetkan keinginan atau kebutuhan wisatawan. Pemasar perlu memahami aspek terkait mengenai perilaku konsumen dalam pariwisata diantaranya mengenai motivasi wisatawan dan proses keputusan berkunjung.

Menurut Page (2009: 87) mengungkapkan bahwa faktor-faktor yang terkait perilaku konsumen dalam melakukan dan mempengaruhi keputusan untuk berkunjung diantaranya faktor ekonomi, faktor social-psikologis dan eksogen. Faktor psikologis terdiri dari motivasi, persepsi, preferensi, demografis, dan sikap. Untuk menarik wisatawan dan memaksimalkan jumlah kunjungan pihak pengelola wisata Taman Kota perlu melakukan pendekatan mengenai perilaku wisatawan yaitu dengan mengidentifikasi dan mengetahui pemahaman tentang motivasi wisatawan dalam melakukan kunjungan wisata.

Motivasi seseorang untuk berwisata timbul oleh beberapa keinginan yang sudah menjadi sifat manusia seperti menyelidiki atau mengenal hal-hal yang belum dikenal. Perjalanan wisata yang dilakukan ini memiliki motivasi yang bervariasi dan setiap orang belum tentu sama motivasinya dalam melakukan perjalanan wisata.

Motivasi merupakan hal yang sangat mendasar dalam studi tentang wisatawan dan pariwisata, karena motivasi merupakan trigger dari proses perjalanan wisata, walaupun motivasi ini seringkali tidak disadari oleh wisatawan itu sendiri. Kajian mengenai motivasi wisatawan mengalami pergeseran dan memandang motivasi sebagai proses singkat untuk melihat perilaku perjalanan wisata, ke arah yang lebih menekankan bagaimana motivasi mempengaruhi kebutuhan psikologis dan rencana jangka panjang seseorang. Seperti yang telah dikemukakan oleh Page (2008: 64) bahwa motivasi merupakan salah satu faktor psikologis yang dapat mempengaruhi keputusan berkunjung. Dengan mengetahui motivasi wisatawan dapat memberikan informasi bagi pengelola wisata dalam memenuhi keinginan dan kebutuhan wisatawan selama mereka mengunjungi suatu kawasan wisata. Pada dasarnya seseorang melakukan suatu kunjungan wisata di motivasi oleh beberapa hal. menurut Jie Zhang dan Carl Marcussen (2007) bahwa motivasi wisatawan dalam melakukan kunjungan diantaranya adalah Nature, Value for Money, Physical Activities.

Nature, yaitu motivasi wisatawan seperti merelaksasikan tubuh, menikmati keadaan, suasana di daya tarik wisata. Di Taman Kota wisatawan dapat menikmati udara yang sejuk dengan dikelilingi pohon yang rindang.

Value for Money yaitu motivasi wisatawan dengan alasan keterjangkauan transportasi ke tujuan destinasi, harga tiket yang murah, dan biaya lainnya yang terjangkau. Untuk mencapai objek destinasi ini sangat mudah jika ditempuh menggunakan angkutan umum maupun kendaraan pribadi karena letaknya yang ditengah kota. Lalu, biaya tiket masuknya pun terbilang murah yaitu Rp.5000,-

Physical Activities, yaitu motivasi wisatawan seperti melakukan aktivitas seperti berolahraga, dan kegiatan lainnya. Di Taman Kota menyediakan lapangan terbuka untuk berolahraga seperti bermain sepakbola, bulutangkis atau kegiatan olahraga lainnya. Lalu di Taman Kota juga terdapat jogging track yang disediakan untuk wisatawan yang ingin berlari kecil.

Tujuan penelitian ini adalah untuk mengetahui motivasi wisatawan di daya tarik wisata Taman Kota di Kota Tangerang Selatan, untuk mengetahui keputusan berkunjung wisatawan di daya tarik wisata Taman Kota di Kota Tangerang Selatan, serta untuk mengetahui pengaruh motivasi terhadap keputusan berkunjung ke Taman Kota di Kota Tangerang Selatan.

\section{KAJIAN PUSTAKA}

\section{A. Perilaku Konsumen dalam Manajemen Pemasaran}

Dalam pariwisata, perilaku konsumen merupakan proses yang dilalui oleh wisatawan dalam mencari, berkunjung, menggunakan, mengevaluasi dan bertindak pasca konsumsi produk, jasa maupun ide yang diharapkan bisa memenuhi harapannya. Tujuan dari perilaku konsumen adalah memahami bagaimana wisatawn melakukan keputusan dalam berkunjung (Hudson, 2008: 40).

Menurut Hudson (2008: 40) perilaku konsumen merupakan kunci dalam aktivitas pemasaran yang dilakukan pemasar untuk mengembangkan, mempromosikan dan menjual produk pariwisata. Dengan memahami pola 
perilaku wisatawan maka pemasar dapat mengetahui dan menargetkan keinginan atau kebutuhan wisatawan. Pemasar perlu memahami aspek terkait mengenai perilaku konsumen dalam pariwisata diantaranya mengenai motivasi wisatwan dan keputusan berkunjung.

Sedangkan menurut Page (2009: 64) mengungkapkan bahwa "faktor faktor yang terkait perilaku konsumen dalam melakukan dan mempengaruhi keputusan untuk berkunjung diantaranya adalah faktor sosial-psikologis, ekonomi dan eksogen". Faktor psikologis diantaranya adalah motivasi, persepsi, demografis, preferensi, dan sikap.

\section{B. Motivasi Wisatawan}

Motivasi merupakan hal yang sangat mendasar dalam studi tentang wisatawan dan pariwisata, karena motivasi merupakan trigger dari proses perjalanan wisata, walaupun motivasi ini seringkali tidak di sadari oleh wisatawan itu sendiri. Kajian mengenai motivasi wisatawan mengalami pergeseran dan memandang motivasi sebagai proses singkat untuk melihat perilaku.

Kajian mengenai motivasi wisatawan mengalami pergeseran dari memandang motivasi sebagai proses singkat untuk melihat perilaku perjalanan wisata, ke arah yang lebih menekankan bagaimana motivasi mempengaruhi kebutuhan psikologis dan rencana jangka panjang seseorang, dengan melihat bahwa motif intrinsik seperti self $a$ Cualization sebagai komponen yang sangat penting.

Menurut Jie Zhang dan Carl Marcussen (2007) menunjukkan bahwa motivasi wisatawan dalam melakukan kunjungan diantaranya:

1. Nature, yaitu motivasi wisatawan dengan alasan menikmati suasana atau keadaan dan juga merelaksasikan tubuh disuatu daya tarik wisata.

2. Value for Money, yaitu motivasi wisatawan dengan alasan keterjangkauan transportasi ke tujuan destinasi, harga tiket yang murah, dan biaya lainnya yang terjangkau.

3. Physical Activities, yaitu motivasi wisatawan untuk menikmati kegiatan yang ditawarkan di daya tarik wisata seperti bersepeda, memancingn dan lainnya.

\section{Keputusan Berkunjung}

Keputusan untuk berkunjung ke suatu tempat wisata destinasi mengambil asumsi dari teori keputusan pembelian. Keputusan untuk membeli timbul karena adanya penilaian objektif atau karena dorongan emosi, keputusan untuk bertindak adalah hasil dari serangkaian aktifitas yang dapat dideskripsikan proses berkunjung.

Menurut Kotler dan Keller (2012: 170) mengemukakan bahwa keputusan berkunjung didasari atas dasar:

1. Pemilihan produk

2. Pemilihan suatu merek

3. Pemilihan saluran pembelian dan kunjungan

4. emilihan waktu kunjungan

5. Jumlah kunjungan

\section{Metode PENELITIAN}

Penelitian ini menganalisis tentang pengaruh motivasi wisatawan lokal terhadap keputusan berkunjung. Motivasi Wisatawan merupakan variabel bebas (independent variable) yang terdiri dari tiga dimensi diantaranya: nature, value for money dan physical activities. Sedangkan Keputusan Berkunjung merupakan variabel terikat (dependent variable) terdiri dari lima dimensi yaitu pemilihan produk, pemilihan merk, pemilihan saluran pembelian dan kunjungan, pemilihan waktu kunjungan dan jumlah kunjungan. Lalu, objek penelitian nya yaitu Taman Kota di Kota Tangerang Selatan.

Pada penelitian ini metode yang digunakan adalah metode penelitian deskriptif dan verifikatif sesuai dengan variabel-variabel yang diteliti.

Ukuran sampel dihitung dengan menggunakan rumus Slovin dalam husein Umar (2010: 146) dan sampel yang diambil untuk penelitian ini sebanyak 100 wisatawan yang berkunjung ke Taman Kota. Teknik pengumpulan data yang digunakan diantaranya dengan studi literature, observasi dan penyebaran angket.

Hipotesis yang diajukan dalam penelitian ini adalah terdapat pengaruh signifikan antara motivasi wisatawan yang terdiri dari Nature (X1), value for Money (X2), dan Physical Activities (X3) terhadap keputusan berkunjung wisatawan (Y). Hipotesis tersebut akan diuji dengan menggunakan analisis regresi berganda dan uji signifikansi.

\section{Hasil PENElitian dan PEMBahasan}
A. Tanggapan Wisatawan Terhadap
Implementasi Taman Kota 
TABEL 1. REKAPITULASI HASIL TANGGAPAN WiSATAWAN MENGENAI MOTIVASI WISATAWAN DI TAMAN KoTA

\begin{tabular}{clcc}
\hline No. & Sub Variabel & Total Skor & \% Skor \\
\hline 1. & Nature & 1508 & 33,60 \\
2. & Value For Money & 1119 & 33,24 \\
3. & Physical Activities & 1117 & 33,16 \\
& Total & 3744 & 100 \\
\hline
\end{tabular}

Tabel 1 menunjukkan rekapitulasi di atas bahwa hasil rekapitulasi tertinggi diperoleh Nature dengan skor rata rata sebesar 377 $(33,60 \%)$. Hal ini dikarenakan keadaan alam yang berada di Taman Kota masih sangat sejuk dan asri, serta kemenarikan dan kelayakan alam yang berada di dalam Taman Kota sebagai tempat wisata membuat wisatawan termotivasi untuk mengunjungi Taman Kota.

Value for Money berada diposisi kedua dengan skor sebesar $373(33,24 \%)$. Hal ini dinilai wisatawan merupakan salah satu faktor yang mempengaruhi motivasi wisatawan untuk berkunjung ke Taman Kota, karena wisatawan tidak harus mengeluarkan uang yang banyak untuk mengunjungi Taman Kota dan juga letak Taman Kota yang strategis dan mudah untuk didatangi wisatawan.

Physical Activities berada diposisi ketiga dengan skor sebesar $372(33,16 \%)$. Hal ini dikarenakan motivasi wisatawan untuk berkunjung ke Taman Kota untuk menikmati keindahan alam ketimbang melakukan kegiatan fisik seperti berolahraga yang menyebabkan Physical Activities menjadi faktor motivasi wisatawan yang memiliki skor terendah.

\section{B. Tanggapan Wisatawan Keputusan Berkunjung di Taman Kota}

TABEL 2. REKAPITULASI HASIL TANGGAPAN WISATAWAN TERHADAP KEPURUSAN BERKUNJUNG WISATAWAN DI TAMAN KOTA

\begin{tabular}{clcc}
\hline No. & \multicolumn{1}{c}{ Sub Variabel } & Total Skor & \% Skor \\
\hline 1. & Pemilihan Produk & 1117 & 20,10 \\
2. & $\begin{array}{l}\text { Pemilihan Suatu } \\
\text { Merk }\end{array}$ & 732 & 19,76 \\
& $\begin{array}{l}\text { Pemilihan Saluran } \\
\text { 3. }\end{array}$ & & \\
& $\begin{array}{l}\text { Pembelian dan } \\
\text { Kunjungan }\end{array}$ & 760 & 20,52 \\
4. & $\begin{array}{l}\text { Pemilihan Waktu } \\
\text { Kunjungan }\end{array}$ & 1100 & 19,80 \\
5. & Jumlah kunjungan & 734 & 19,82 \\
& $\quad$ Total & 4443 & 100 \\
\hline
\end{tabular}

Hasil rekaputulasi tanggapan wisatawan mengenai keputusan berkunjung tanggapan tertinggi diperoleh pemilihan saluran pembelian dan kunjungan dengan rata-rata skor 380 $(20,52 \%)$. Dibandingkan dengan tanggapan skor terendah yaitu pemilihan suatu merk yang hanya mendapatkan rata-rata skor $366(19,76 \%)$. Akan tetapi, dapat dikatakan bahwa keputusan berkunjung wisatawan ke Taman Kota sudah tinggi, di mana sebagian besar wisatawan yang telah berkunjung sudah beberapa kali mengunjungi Taman Kota dalam satu bulan dan juga banyak dari wisatawan yang berkunjung ke Taman Kota mengajak teman, saudara dan juga anaknya untuk berkunjung ke Taman Kota

C. Pengaruh Motivasi Wisatawan Lokal Terhadap Keputusan Berkunjung ke Taman Kota di Kota Tangerang Selatan

Persamaan regresi berganda untuk pengaruh motivasi wisatawan terhadap keputusan berkunjung wisatawan dapat dinyatakan sebagai berikut:

$\mathrm{Y}=4,115+1,361 \mathrm{X} 1+1,060 \mathrm{X} 2+1,204 \mathrm{X} 3$

Keterangan:

$\mathrm{Y} \quad=$ Keputusan Berkunjung

$\mathrm{a} \quad=$ Konstanta

$\mathrm{X} 1=$ Nature

$\mathrm{X} 2$ = Value for Money

$\mathrm{X} 3=$ Physical Activities

Hasil analisis menunjukkan nilai konstanta 4,115 artinya jika $X_{1}, X_{2}, X_{3}$ diabaikan maka tingkat keputusan berkunjung adalah sebesar 4,115. Apabila nature $(1,361)$ dinaikan satu satuan maka nilai tingkat keputusan berkunjung akan naik 1,361. Untuk setiap kenaikan satu satuan value for money $(1,060)$ maka tingkat keputusan berkunjung akan naik sebesar 1,060. Sedangkan untuk setiap kenaikan satu satuan physical activities $(1,204)$ maka tingkat keputusan berkunjung akan naik sebesar 1,204. Sehingga nilai keputusan berkunjung akan berubah menjadi 7,740.

Selain analisis regresi juga dilakukan uji signifikansi menggunakan uji $\mathrm{F}$ dan uju t. Uji $\mathrm{F}$ digunakan untuk mengetahui seberapa besar pengaruh keseluruhan variabel bebas terhadap variabel terikat. Uji $\mathrm{F}$ dapat dilakukan dengan membandingkan $F_{\text {hitung }}$ dengan $F_{\text {tabel }}$ untuk menguji signifikansi dari analisis regresi. Dari hasil uji $\mathrm{F}$ atau uji keseluruhan, maka didapat nilai $\mathrm{F}$ adalah sebesar 65.068 dengan tingkat signifikansi 0,000 atau < dari 0,050. Hal tersebut dapat diartikan bahwa secara simultan Motivasi Wisatawan memiliki pengaruh yang signifikan terhadap Keputusan Berkunjung ke Taman Kota.

Selanjutnya uji $\mathrm{t}$ untuk mencari tahu signifikansi pengaruh dari masing-masing variabel bebas terhadap variabel terikat. Hasilnya adalah sebagai berikut

1. Nilai $t_{\text {hitung }}$ untuk dimensi nature (X1) sebesar 10,092>1,985 dan signifikansi 
$0,000<0,05$, ini berarti bahwa terdapat pengaruh signifikan antara sub variabel nature terhadap keputusan berkunjung wisatawan.

2. Nilai $t_{\text {hitung }}$ untuk dimensi value for money (X2) sebesar 6,004>1,985 signifikansi $0,000<0,05$, ini berarti terdapat pengaruh signifikan antara sub variabel value for money terhadap kemputusan berkunjung wisatawan.

3. Nilai thitung untuk dimensi physical activities (X3) sebesar 7,331 > 1,985 dan signifikansi $0,000<0,005$, ini berarti terdapat pengaruh signifikan antara sub variabel physical activities terhadap keputusan berkunjung wisatawan.

Berdasarkan ketiga dimensi, terdapat 3 dimensi yang memiliki pengaruh signifikan secara parsial terhadap keputusan berkunjung yaitu nature, value for money dan physical activities.

\section{KESIMPULAN}

Penilaian motivasi wisatawan yang berkunjung ke Taman Kota terdiri dari nature, value for money dan physical activities. Dari sub variabel tersebut, sub variabel nature memiliki nilai paling paling tinggi. Hal ini dikarenakan Taman Kota memiliki suasana alam yang sangat indah dan juga sangat sejuk lalu memiliki udara yang segar sehingga membuat wisatawan ingin melakukan kunjungan ke Taman Kota dengan tujuan untuk menyegarkan diri, melepaskan penat dari rutinitas yang biasanya dilakukan sehari-hari seperti bekerja dan juga sekolah. Sub variabel physical activities memiliki nilai paling rendah. Hal ini dikarenakan motivasi wisatawan untuk berkunjung ke Taman Kota lebih memilih untuk menikmati keindahan alam ketimbang melakukan kegiatan fisik seperti berolahraga yang menyebabkan Physical Activities menjadi faktor motivasi wisatawan yang memiliki skor terendah.

Secara umum gambaran mengenai keputusan berkunjung Taman Kota yang terdiri dari pemilihan produk, pemilihan merk, pemilihan saluran pembelian dan kunjungan, pemilihan waktu kunjungan dan jumlah kunjungan berada pada kategori tinggi. Indikator dari keputusan berkunjung yang memperoleh penilaian paling tinggi adalah pemilihan saluran pembelian dan kunjungan. Hal ini menunjukkan bahwa Taman Kota adalah destinasi yang memiliki letak yang strategis untuk dikunjungi oleh wisatawan dan juga untuk dapat mengunjungi Taman Kota karena letaknya yang berada di tengah kota Tangerang Selatan, dan juga wisatawan yang ingin berkunjung ke Taman Kota dengan mudah mendapatkan tiket masuk yang terjangkau.

Berdasarkan pengujian hipotesis dengan teknik analisis regresi berganda, menunjukkan bahwa motivasi wisatawan dengan dimensi nature, value for money dan physical activities memiliki pengaruh signifikan terhadap keputusan berkunjung wisatawan baik secara simultan maupun parsial. Berdasarkan hasil penelitian ini menunjukkan bahwa variabel motivasi wisatawan memiliki pengaruh terhadap keputusan berkunjung wisatawan Taman Kota.

Bagian ini merupakan penutup artikel. Simpulan ditulis tanpa nomor, dan disajikan dalam bentuk paragraf. Implikasi dan keterbatasan penelitian juga disajikan dalam bentuk paragraf.

\section{DAFTAR RUJUKAN}

Hudson, Simon. (2008). Tourism And Hospitality Marketing: A Global Perspective. London : SAGE Publication Ltd.

Page, Stephen. (2009). Tourism Management: Managing For Change 3th Edition. Burlington. USA

Jie Zang And Carl Marcussen. (2007). Tourism Motivation, Market Segmentation And Marketing Strategies. Charleston. South Carolina. USA

Umar, Husein. (2010). Metode Penelitian Untuk Skripsi Dan Tesis Bisnis Edisi Kedua. Jakarta: Rajawali Pers.

Kotler, P, Dan Keller, K.L. (2012). Marketing Management 14th Edition. Pearson Education Inc. 
